DOI: $10.1515 / \mathrm{rpp}-2017-0060$

Postgraduate Student, OLENA SAMBORSKA

Khmelnytskyi National University

Address: 11 Instytutska St., Khmelnytskyi, 29016, Ukraine

E-mail: len4uk19911991@gmail.com

\title{
SOME PECULIARITIES IN TRAINING FUTURE MASTERS IN TECHNOLOGY EDUCATION IN EUROPEAN COUNTRIES
}

\begin{abstract}
In the article, the importance of studying foreign experience in order to improve quality of future Masters' training in higher education institutions has been justified. The main peculiarities of training Masters in Technology education in European countries, namely, in Germany, Sweden and France have been outlined. It has been revealed that European education systems aim at developing future handicraft and technology teachers' practical abilities and skills. It has been established that organization of teacher placements in each European country somehow differs: in Germany, teacher placement lasts approximately one or two years; in Sweden, teacher placement is rather cross-cutting; in France, teacher placement contributes to individualizing future technology teachers' training. It has been determined that syllabi for training handicraft and home economics teachers in Germany are oriented toward not a specific discipline, but toward a set of specialties within the framework of general professional industry. It has been specified that modern challenges and paradigm shifts in education have led to implementation of the latest reform in training Future Masters in Technology Education in Sweden. It has been justified that modern French teacher education, in particular, education of technology teachers, is based on the principles of individualization. It has been noted that syllabi of European higher education institutions are rather variative, yet they always contain three types of disciplines - compulsory, partially elective and completely elective. Based on the research findings, it has been concluded that exchanging experience is extremely necessary nowadays and will contribute to improving Ukrainian system of teacher education. It has been determined that education systems in Germany, Sweden and France possess several advantages, namely, information openness, a diversified network of higher education institutions, favourable conditions for lifelong learning.

Keywords: Master in Technology Education, handicraft and technology teacher, professional training, educational model of training, curriculum, teacher placement, partner schools, thesis.
\end{abstract}

\section{INTRODUCTION}

The $21^{\text {st }}$ society is awaiting for a teacher who possesses a system of professional knowledge and skills, is able to maintain and improve the level of psycho-pedagogical and professional training, is familiar with the latest achievements and scientific and pedagogical discussions at the national and global levels, aspires to sustainable personal development and is ready for pedagogical activity. It should be noted that Ukrainian teachers are not competitive enough in the international labour market.

Therefore, on today's agenda is the need for studying theory and practice of organizing teaching education in leading European countries, in particular, Germany, Sweden and France, which over the past years have gained positive experience in reforming teacher education. 


\section{THE AIM OF THE STUDY}

The aim of the study is to outline the main peculiarities of training Masters in Technology Education in European countries, in particular, in Germany, Sweden and France.

\section{THEORETICAL FRAMEWORK AND RESEARCH METHODS}

Analysis on psycho-pedagogical and philosophical scientific sources proves that training of Masters in Technology Education has been studied by many scholars all over the world. Ukrainian and foreign scholars such as K. Borg, J. Christensen, O. Holmberg, V. Lashchykhina, L. Lebedyk, N. Machynia, N. Machynska, J. McDonnell, N. Nosovets, F. Rauner, S. Yashchuk, I. Zhernoklieiev et al. have analyzed the problems of future teachers' training, in particular, handicraft and technology teachers' training, in European countries. However, little attention has been paid by scholars to studying the peculiarities of training Masters in Technology Education in Germany, Sweden and France.

In order to achieve the aim of the study, we have used studied foreign scientific and pedagogical literature and with the help of such method as comparative analysis generalized and individualized our research findings.

\section{RESULTS}

Teacher training is one of the most important objectives of education, since the teacher was, is and will be called to achieve its main goals. The concept of professional teacher training has changed along with the evolution of views on the aim of education as well as ideas on the teacher's professional features and qualities. Every country is interested in training such teachers who would know scientific theory and be able to apply modern teaching methods (Nosovets, 2015, p. 68).

At the present stage of society development, teacher training is of great significance for the national education system, since the teacher is responsible for forming a free individual, who must possess not only certain knowledge and professional competency, but also combine intellectual potential with moral consciousness and public responsibility. In this regard, training of highly qualified teaching staff requires special attention in the process of harmonizing the European educational space. This aspect is very important for Ukraine, especially in the context of education reforms and the European integration process. Reforming Ukrainian teacher education, one should take into account innovative experience of foreign countries. Modern diversity of approaches and strategies for teacher training is determined by historical, social, cultural and economic factors for development of each country (Nosovets, 2015, p. 68).

Of special scientific interest for our study is the process of training teaching staff in the Federal Republic of Germany, which develops in accordance with the following provisions;

- education is defined as one of priority directions in the state policy of the European Union;

- teacher education under modern conditions takes into account new social realities associated with development of globalization, expansion of dialogue of cultures, use of computer technologies;

- the labour market in European countries affects development of teacher education;

- there appears to be a need for enhancing the links between teacher education institutions (training in higher education institutions, advanced training, staff retraining) (Machynia, 2006, pp. 46-47).

In Germany, they train handicraft and home economics teachers at universities. The training consists of two stages, namely, university studies (9 terms) and one-two year 
teacher placement, which is held in non-university educational institutions. Each stage is followed by the state exams, which are conducted by the state examination bodies located in the structure of ministries of education of regional subjects (Yashchuk, 2015).

In Germany, there are educational models for training handicraft and home economics teachers, developed in the 1920's. In literary sources, they are conventionally designated as "specialist", "teacher" and "professional training teacher".

There are some modern problems of training handicraft and home economics teachers, which are actively discussed within pedagogical community in Germany. Many scholars indicate that academization of teacher education causes negative consequences for professional training. Thus, Prof. F. Rauner outlines the following unfavorable trends, namely, graduates' lack of integrated practical skills; insufficient productive experience, which they can obtain only in the process of working at enterprises; an insufficient level of competency in technological processes; inconsistency between applied knowledge obtained in an educational institution and the current level of fundamental science development in relevant fields; low status of the profession in general. Moreover, none of the models for training handicraft and home economics teachers have escaped criticism, including the "centrist' model for professional training teachers. According to F. Rauner, the teachers trained within this model, on the one hand, possess less technical knowledge than engineers and, on the other hand, they possess less pedagogical knowledge than general education teachers (Berufsbildung in Europa, 2005).

General structure of the syllabi for training handicraft and home economics teachers consists of the following parts: $50 \%$ of training comprises an in-depth study of professional disciplines; $25 \%$ - psychological and pedagogical disciplines and teaching methodology; $25 \%$ - general education disciplines or additional specialization depending on the region and the educational institution.

In Germany, syllabi for training handicraft and home economics teachers are oriented toward not a specific discipline (in the case of general education subjects teachers), but toward a set of specialties within the framework of general professional industry (Yashchuk, 2015).

So, education is one of the priority directions in German state policy, which consequently affects the system of training specialists, in particular, future teachers of handicraft and home economics. Such training is mostly based on future handicraft and home economics teachers' mastering practical abilities and skills due to two-stage training. Teacher placement can last approximately one or two years at university-affiliated institutions. In our opinion, German experience in organizing teacher placement for future teachers of handicraft and home economics deserves special attention as its positive aspects can be implemented into the education process of Ukrainian higher education institutions.

Of great importance for our study is also Swedish experience in organizing professional training of Sloyd teachers. It must be noted that the word "sloyd" is derived from the Swedish word Sloyd, which translates as crafts, handicraft, or handiwork. Thus, Sloyd for girls and Sloyd for boys were introduced as elective school subjects about 120 years ago in Swedish elementary schools. Later on the name of the subject changed to Textile Sloyd and Wood and metal Sloyd. Since 1969 it is regarded as one subject, Sloyd, with two branches. Nowadays the pupils are trained ins both branches at elementary level. At lower secondary level the can usually chose branch for shorter or longer periods of time or for specific projects. At higher secondary level there are no Sloyd subjects, but Technology, Design, Fashion and more vocational like training ins carpentry, dress-making et (Borg, 2006). 
In order to analyze the main peculiarities of Sloyd teachers' training in Sweden, we believe it necessary to outline the main features of Swedish higher education system.

Thus, higher education in Sweden is divided into three levels; the first, second and third. We have outlined general features of each in the following list:

- Högskoleexamen (University Diploma) is the first level of higher education and requires 120 higher education credits and a diploma project;

- Kandidatexamen (Degree of Bachelor) is the first level of higher education and requires 180 higher education credits. At least 90 higher education credits with increasingly in-depth studies including a diploma project of 15 higher education credits have to be completed in the main field of study;

- Magisterexamen (Degree of Master (One Year)) is the second level of higher education and requires 60 higher education credit. At least 30 credits have to be completed in the main field of study including a thesis of 15 credits;

- Masterexamen (Degree of Master (Two Years)) is the second level of higher education and requires 120 higher education credits. At least 60 credits have to be completed in the main field of study including a thesis of 30 credits;

- Licentiatexamen (Degree of Licentiate) is the third level of higher education and requires at least 120 higher education credits including a thesis of at least 60 credits;

- Doktorsexamen (Degree of Doctor) requires 240 higher education credits including a thesis of at least 120 credits. The thesis has to be defended publicly (Halmstad University, 2008).

Future Masters in Technology Education in Sweden are expected to combine teaching techniques with previous or modern traditions, as well as be aware of traditional crafts in different cultures.

It must be noted that a special role in training future Masters in Technology Education in Sweden is played by teaching placement, which is held at partner schools. Teaching placement, which consists of four stages, is rather cross-cutting. According to the system of indicators by O. Holmberg (2003), professional training of students-teachers is carried out on orientational, initial, technological and professional levels. This reveals quality dynamics of students' practical training.

Teaching placement is followed by writing thesis (dissertation). This activity is performed by the students based on the experience obtained at partner schools. The material for the thesis is to be collected during four levels of practical training. The thesis itself deals with recommendations that can be actively used by partner school teachers and university lecturers in order to modernize and improve technologies of teaching and learning.

Modern challenges and paradigm shifts in education have led to implementation of the latest reform in training Future Masters in Technology Education in Sweden, whose main objective is to promote the role of the teacher both at school and in society. Prerequisite for this is a well-elaborated strategy for developing professional training of future Sloyd teachers.

Therefore, positive ideas of Swedish experience in organizing teaching placement can be implemented into the system of handicraft and technology teachers' professional training in Ukraine.

The system of training future Masters in Technology Education in France has its own peculiarities that should be highlighted in the context of our study.

Integration of French teacher education into the European educational space is carried out through introduction of Trans-European programmes with the prospect of their 
prolongation: Socrates, Leonardo da Vinci, Tempus, Europass etc. These programmes are oriented toward designing common European standards for training higher education graduates, in particular, teachers. The aforementioned programmes are aimed at facilitating mobility of students and teachers in the context of convergence in education systems as well as studying teaching experience and cooperation (Lashchykhina, 2007).

The system of teacher education of future Masters in France is regulated by the University Institute for Teachers Training (Instituts Universitaire de Formation des Maitres IUFM), established in 1990. The Institute is aimed at forming common programmes of teacher education for every teacher, regardless of their specialization. Such training is designed for those who already have a degree. After two-year training, trainees obtain a relevant qualification and civil servant status. General duration of French teacher education is equal to 5 years, and its structure formally corresponds to the Anglo-Saxon model of higher education $(3+2)$. The IUFM programmes for teacher training include three blocks: subject-specific training; psycho-pedagogical training, including didactics and methodology; teacher placement (Lebedyk, 2011, pp. 32-33).

According to V. Lashchykhina (2006), scientific and theoretical studies on French education system allow outlining recommendations for teaching staff training in Ukraine and thus implementing innovative ideas of French experience into Ukrainian system of teacher education:

- introducing professional selection of teaching staff due to vocational guidance courses in higher education institutions;

- improving the content, forms and methods of teacher training;

- developing curricula and syllabi focused on professional practical training of future teachers;

- combining theoretical and practical components of teacher training;

- maintaining scientifically justified consistency while determining general educational, subject-specific, psychological and pedagogical components of teacher training.

Modern French teacher education, in particular, education of technology teachers, is based on the principles of individualization. The latter involves not mere differentiation of the professional training content, but also creation of favourable conditions for the student to choose certain courses. Theorists and practicians of professional teacher training aim to help and teach future technology teachers, namely, Masters in Technology Education, to be independent and responsible for their personal and professional development (Guide des études, 2008)

Teaching placement is one of the most important tools of individualization in training future technology teachers. There are three types of teaching placement: supervised placement; full-time placement; college-based placement (IUFM d'Alsace, 2012). Teaching placement ensures forming professional skills and behaviour of the trainee teachers, as well as gathering relevant material for their thesis.

Modern teacher education in France aims at balancing theoretical and practical training, combining personality- and activity-based approaches. Therefore, we believe it necessary to implement the abovementioned positive aspects of French experience in organizing training of future technology teachers. In particular, individualization of future technology teachers' training deserves special attention since it motivates future specialists toward personal and professional development.

It must be noted that the number of academic hours allocated for various disciplines within curricula for training Masters in Technology Education significantly 
differ. The syllabi of European higher education institutions are rather variative, yet they always contain three types of disciplines - compulsory, partially elective and completely elective (Christensen \& McDonnell, 2005, pp. 295-315).

\section{CONSLUSIONS}

Theoretical analysis on European experience of training Masters of Technology Education, namely, future handicraft and technology teachers can greatly modernize Ukrainian system of teaching staff training. It has been concluded that exchanging experience is extremely necessary nowadays and will contribute to improving Ukrainian system of teacher education. It has been determined that education systems in Germany, Sweden and France possess several advantages, namely, information openness, a diversified network of higher education institutions, favourable conditions for lifelong learning.

The prospects for further researches in this direction consist in studying technologies for training Masters in Technology Education in European countries.

\section{REFERENCES}

1. Borg, K. (2006). What is sloyd. Tradition in transition, 2-3, 31-35.

2. Berufsbildung in Europa. (2005). Zur Begrüundung eines europäischen Qualifikationsrahmens. Bremen: ITB.

3. Christensen, J. C., \& McDonnell, J. (2005). The career lattice: a structure for planning professional development. In L. Kremer-Haydon (Ed.), Teacher professional development: a multiple perspective approach (295-315). Amsterdam: Berwyn.

4. Guide des études (2008). Professeurs des collèges et lycées ou conseillers d'éducation. Récupéré de http://www.aixmrs.iufm.fr/etu1/pdf/GdE_PCL1.pdf.

5. Halmstad University. (2008). The Swedish Higher Education System. Retrieved from http://www.hh.se/download/18.70cf2e49129168da015800069647/1341267422713/the _swed_high_system.pdf.

6. Holmberg, O. (2003). Partner Schools. Journal Malmo School of Education, 4, 5.

7. IUFM d'Alsace. (2012). Université de Strasbourg. Récupéré de http://iufm.unistra.fr/.

8. Lashchykhina, V. P. \& Yevtukh, M. B. (2006). Universytetska osvita u XXI stolitti: realii i problemy (teoretychnyi analiz). Teoretychni pytannia kultury, osvity ta vykhovannia, 31, 198-203.

9. Lebedyk, L. V. (2011). Pedahohichna pidhotovka mahistriv u vyshchykh ekonomichnykh navchalnykh zakladakh. Poltava: RVV PUET.

10. Machynska, N. I. \& Sysoieva, S. O. (2013). Pedahohichna osvita mahistrantiv vyshchykh navchalnykh zakladiv nepedahohichnoho profiliu. Lviv: LvDUVS.

11. Makhynia, N. V. (2006). Systema pidvyshchennia kvalifikatsii pedahohichnykh kadriv u Nimechchyni. Materialy Vseukrainskoi naukovo-praktychnoi konferentsii. Cherkasy: ChNU.

12. Nosovets, N. M. (2015). Profesiina pidhotovka maibutnikh uchyteliv u krainakh zakhidnoi Yevropy. Visnyk Chernihivskoho natsionalnoho pedahohichnoho universytetu. Seriia: Pedahohichni nauky, 130, 68-72.

13. Yashchuk, S. M. (2015). Profesiina pidhotovka mahistriv tekhnolohichnoi osvity: teoriia ta metodyka. Uman: FOP Zhovtyi O. O.

14. Zhernoklieiev, I. V. (2011). Suchasnyi stan i reforma systemy pidhotovky maibutnikh vchyteliv tekhnolohii ta profesiinoho navchannia u Shvetsii. Problemy trudovoi ta profesiinoi pidhotovky, 16, 43-50. 